\title{
Preneoplasia and carcinogenesis of the oral cavity
}

\author{
Naoki Watanabe ${ }^{1}$, Tsunemasa Ohkubo ${ }^{2}$, Masahito Shimizu ${ }^{3}$ and Takuji Tanaka ${ }^{*}$ \\ *Correspondence: takutt@gmhosp.gifu.gifu.jp \\ CrossMark \\ $\leftarrow$ Click for updates

\begin{abstract}
'Department of Diagnostic Pathology (DDP) \& Research Center of Diagnostic Pathology (RC-DiP), Gifu Municipal Hospital, 7-1 Kashima-cho, Gifu City, Gifu 500-8513, Japan.

${ }^{2}$ Department of Oral Surgery, Takayama Red Cross Hospital, 3-11 Tenma-cho, Takayama City. Gifu 506-0025, Japan.

${ }^{3}$ Department of Gastroenterology/Internal Medicine, Gifu University Graduate School of Medicine, 1-1 Yanagido, Gifu 501-1194, Japan.
\end{abstract}

\begin{abstract}
Oral cancer, ranking sixth in the cancer incidence worldwide, is one of the most common neoplasms. Preneoplastic or premalignant (precancerous) lesions are lesions that can potentially transform into malignancy in a variety of tissues, including the oral cavity. Such oral lesions may be caused by tobacco use, exposure to the human papillomavirus and chewing of the betel nut. These substances contain carcinogens and/or tumor promoters. The mucosa of the oral cavity is covered with squamous epithelium and is relatively resistant to injury. However, exposure to these substances can cause the mucosa to undergo changes. The changes are usually initiated by a leukoplakic patch. While some leukoplakic patches recover and resolve, others progress to squamous cell carcinoma with or without invasion. Other premalignant lesions include oral submucous fibrosis, which is a potentially malignant condition caused by the abuse of the betel nut. Understanding the histology, premalignant states and molecular mechanisms of oral carcinogenesis may facilitate the development of novel strategies for the prevention and treatment of oral cancer. In addition, early detection is of critical importance to improve the survival rates of patients with oral cancer. In this review, we will summarize these aspects of oral cancer development, beginning from the histology of the oral cavity.
\end{abstract}

Keywords: Oral cancer, premalignant lesions, oral carcinogenesis, dysplasia; animal model, molecular mechanisms, chemoprevention

\section{Introduction}

Over $90 \%$ of all malignancies (Table 1 ) of the oral cavity are squamous cell carcinomas (SCCs) arising from the lining mucosa, the squamous epithelium. Worldwide, oral cancer (buccal cancer) is the sixth most common cancer, representing about $5.5 \%$ of all malignancies. It is more common than uterine cervical cancer [1]. The incidence varies by geographical regions, being higher in the developing countries, with relative frequencies of almost 50\% in some parts of southeast Asia and Brazil [2]. It is relatively uncommon in the developed world, except in parts of France. Age-adjusted incidence rates of oral cancer range from 2.2 per 100,000 males in Japan and several industrialized countries to 15-30 per 100,000 in southern Asia [3], with more than 500,000 new cases projected worldwide annually [4]. In Japan, the number of annual deaths from all oral cancers showed a 4.5-fold increase from 698 to 3,155 from 1950 to 1993. Tongue cancer is the most common type of oral cancer, and contributes to about $40-60 \%$ of all oral cancer deaths. Such oral cancer is generally more prevalent in males, but in the high-risk areas of southern Asia, the rates in females are equivalent to those in males [5]. The incidence of oral tumors has recently been increasing in developed countries, with the increase in risk being seen in younger people, particularly young females [6]. It is mainly seen in males over middle age (although it is increasing in younger people), tobacco users, and lower socioeconomic groups.

The etiological factors [7] acting on a genetically susceptible individual include tobacco use ( $75 \%$ of people with oral cancer smoke), betel use (Bidi leaf, which is often combined with tobacco, spices, slaked lime, and areca nut), alcohol consumption, a diet poor in fresh fruit and vegetables, infective agents (Candida, viruses), immune deficiency, and (in the case of lip carcinoma) exposure to sunlight (Table 2). The oral cavity can be the site of a variety of HPV-related lesions [8-10], some of which are microscopically and behaviorally analogous to those located in the genital tract [11]. The verruca, condylomas, and 
Watanabe et al. Oncology Discovery 2015,

http://www.hoajonline.com/journals/pdf/2052-6199-3-1.pdf

doi: 10.7243/2052-6199-3-1

Table1. The histopathology of oral malignant neoplasms.

\begin{tabular}{ll}
\hline Common & Squamous cell carcinoma (SCC) \\
\hline & Specific types of SCC: \\
& Verrucous carcinoma \\
& Basaloid SCC \\
& Adenoid SCC \\
& Adenosquamous carcinoma \\
& Papillary SCC \\
& $\begin{array}{l}\text { Malignant salivary gland tumor; malignant } \\
\text { melanoma; malignant lymphoma; malignant } \\
\text { neoplasms of bone and connective tissue, some } \\
\text { malignant odontogenic tumors; maxillary antral } \\
\text { carcinoma; Langerhans's cell histiocytoses; } \\
\text { Kaposis sarcoma; metastatic neoplasms (from } \\
\text { breast, lung, kidney, stomach or liver cancer) }\end{array}$ \\
\hline
\end{tabular}

Table 2. Etiologic factors of oral cancer.

Tobacco smoking: pipes, cigars, cigarettes, bidis, reverse smoking

Smokeless tobacco: snuff dipping, tobacco sachets, tobacco chewing

Chewing habit: betel chewing, betel quid (pan), areca nut

Alcohol: spirits, wines and beers, alcohol and tobacco synergism

Diet and nutrition: iron deficiency, vitamin $\mathrm{A}, \mathrm{E}$ and $\mathrm{C}$ deficiencies, nutritional deficiencies and alcoholism

Dental factors: poor oral hygiene, faulty restorations, sharp edges of teeth, ill-fitting dentures

Ultraviolet light

Viruses: herpes simplex virus (HSV), human papillomavirus

(HPV), human immunodeficiency virus (HIV)

Immunosuppression: drug-induced, etc.

Chronic infection: candidiais, syphilis

Occupational: textile workers, etc.

papillomas often exhibit koilocytosis as a sign of cytopathologic effect. Atypical nuclear changes may be present, especially in HIV-positive patients [12]. An etiologic role for HPV has also been suggested for verrucous carcinoma [13] and squamous cell carcinoma, including some of its variants $[14,15]$. The benign oral lesions are statistically associated with HPV types $2,4,6,11,13$, and 32 , and the malignant ones with HPV types 16,18 , and $33[11,16]$. Among the carcinomas, those with the highest incidence of HPV detection are the poorly differentiated non-keratinizing tumors of the tonsil seen in young individuals $[\mathbf{1 7 , 1 8}]$. Many of the latter tumors express p16 protein [19]. HPV-positive oropharyngeal cancers are also more likely to show basaloid morphology [20]. Human papillomavirus (HPV) vaccine is now approved for use to prevent cancers developing in several tissues, including oral cancer [21].

Additional primary neoplasms associated with these etiological factors arise mainly in the aerodigestive tract.
These second primary neoplasms are found in up to $25 \%$ of people who have had oral cancer for over three years, and in up to $40 \%$ of those who continue to smoke. Similarly, patients with lung cancer are at risk of developing second primary oral cancers. Such findings indicate the presence of so-called "field cancerization" [22,23].

\section{Review \\ Anatomy}

The oral cavity is externally bounded by the internal mucosa of the cheeks and the vermillion border of the lips. It is superiorly formed by the hard and soft palates, and inferiorly by the anterior two-thirds of the tongue, with the attached mucous membsranes of the floor of the mouth. The posterior boundary of the oral cavity, which forms a junction with the oropharynx, is the fauces. This is defined superiorly by the posterior edge of the soft palate and uvula and laterally by the tonsillar pillars. The inferior margin corresponds to a line across the circumvallate papillae of the tongue.

\section{Histology}

Most of the oral cavity is lined by nonkeratinizing squamous epithelium. Portions directly involved in chewing, including the hard palate and parts of the gingiva, are lined by squamous mucosal epithelium with varying degrees of orthokeratotic and parakeratotic epithelium. These are associated with considerable thickening of the underlying rete ridges. Identical histological changes develop in areas of chronic irritation, which are most often associated with poorly fitting dentures. The tongue is covered by specialized filiform, fungiform and circumvallate papillae involved in chewing and taste. Scattered melanocytes are normally present in the oral squamous epithelium. They are difficult to find on hematoxylin and eosin (H \& E)-stained sections, but appear as clear cells in the basal epithelial layer and are positive for the S-100 protein immunohistochemically. The stratified epithelium lining the papillary wall of the cleft contains numerous taste buds, which show neurone-specific enolase-positive reactions immunohistochemically. The lamina propria of the oral cavity is filled with seromucinous glands, which are prominent in the lamina propria of the hard palate. The stroma around teeth often contains epithelial nests of apparent odontogenic origin.

\section{Oral premalignancy}

Potentially premalignant lesions or conditions may include some fibrosis and chronic immunosuppression. About half of oral carcinomas have associated leukoplakia. Rare causes of oral cancer include tertiary syphilis, discoid lupus erythematosus, dyskeratosis congenital and Plummer-Vinson syndrome (iron deficiency and dysphagia). The two most common and well-documented clinical oral tissue changes that indicate a precancerous state are leukoplakia and erythroplakia [24].

The classification based on clinical criteria elaborated in 1972 by the WHO distinguishes a "precancerous lesion (a 
morphologically altered tissue in which cancer is more likely to occur than in its apparently normal counterpart)" from a "precancerous condition (a generalized state associated with a significantly increased risk of cancer)" [25]. In the oral cavity, the former includes leukoplakia and erythroplakia (Table 3). The latter includes syphilis, oral submucous fibrosis, actinic cheilitis, sideropenic dysphagia, and lichen planus. However, the fact that a "precancerous condition" can affect other parts of the body is of no concern to the increased risk of oral cancer, only the "precancerous lesions" that these conditions can produce in the oral cavity may occasionally undergo a malignant transformation.

Table 3. Precancerous lesions and conditions of the oral mucosa (clinical terms).

\begin{tabular}{|c|c|}
\hline \multirow[t]{3}{*}{ Precancerous lesions } & $\begin{array}{l}\text { Leukoplakia (proliferative verrucous } \\
\text { leukoplakia, smokeless tobacco } \\
\text { keratosis, candidal leukoplakia) }\end{array}$ \\
\hline & Erythroplakia \\
\hline & Erythroleukoplakia \\
\hline \multirow[t]{5}{*}{ Precancerous conditions } & Oral submucous fibrosis \\
\hline & Actinic cheilitis \\
\hline & Lichen planus \\
\hline & $\begin{array}{l}\text { Sideropenic dysphagia } \\
\text { (Plummer-Vinson syndrome) }\end{array}$ \\
\hline & Discoid lupus erythematosus \\
\hline
\end{tabular}

As noted above, oral precancerous lesions classically included leukoplakia (leukos, "white" and plasis, "formation"), erythroplakia (erythros, "red"), and erythroleukoplakia, a mixture of the first two lesions. These are merely clinical terms meaning, respectively, "white", "red" and "red and white lesion", but more complicated definitions based on the pathological findings have been developed.

\section{Leukoplakia}

The clinical concept of oral epithelial premalignancy is more than 150 years old. Sir James Paget first described an association between an oral lesion ("ichthyosis") and the subsequent development of tongue carcinoma. Nineteen years earlier, Paget had found that white oral mucosal patches in pipe smokers bore a risk of transforming into cancer. Seven years after Paget's report, Schwimmer also described white lesions of the tongue, which developed into cancer in patients with tertiary syphilis, which he termed "leukoplakia" [26]. Thus, the term "leukoplakia" and its association with oral mucosal premalignant disease have been present in the literature for 129 years. Similarly, a red lesion of the glans penis in a syphilitic man that evolved into cancer was designated "erythroplasia" by Queyrat. In 1924, Darier first described a red oral mucosal lesion with the potential to turn into cancer and designated this the "erythroplasia of Queyrat" [27].
The biological basis for the concept of oral premalignancy has been established by carcinogenesis studies [7,28-30]. From the earliest studies in mouse and hamster models to the more recent molecular and/or genetic research, studies have confirmed that cancer is not the result of a single random event, but requires multiple "hits" over time that result in accumulated changes allowing abnormal cells to proliferate while resisting both apoptosis and the body's own immune surveillance. The pathological process of carcinogenesis requires time, as well as an appropriate environment, in order to produce a clinically perceptible result. The fact that both time and a proper environment are required in most instances explains why the people at the greatest risk of oral cancer are older adults who habitually use products such as tobacco and alcohol that contain carcinogens or that act as co-carcinogens and tumor-promoters.

For some reason, the clinicopathological concept of leukoplakia (Figure 1) remains elusive and confusing to many clinicians. Leukoplakia refers to a white patch that cannot be removed easily or recognized as another clinicopathological entity. Because this lesion is somewhat a diagnosis of exclusion, the etiological factors that contribute to its formation are varied. These include, but are not restricted to, tobacco and alcohol use, chronic trauma and infection, specifically candidiasis. Leukoplakia is strictly a clinical term. Its use as a microscopic diagnosis is inappropriate. This clinical entity shows a constellation of microscopic findings, some of which fall in the dysplastic or even invasive realm. Leukoplakia can show a range of pathological changes histologically, and the only way to assess the seriousness of the lesions is by performing a biopsy to determine the presence or absence of dysplasia, and if it's present, its severity. It was reported that $80 \%$ of over 3,000 cases of leukoplakia showed hyperkeratosis and/or acanthosis without evidence of dysplasia [31]. For the oral mucosa, parakeratosis connotes no greater malignant risk than orthokeratosis. When biopsy specimens are examined, roughly $10-25 \%$ of leukoplakias will show microscopic evidence of dysplasia or early invasive sequamous cell carcinoma.

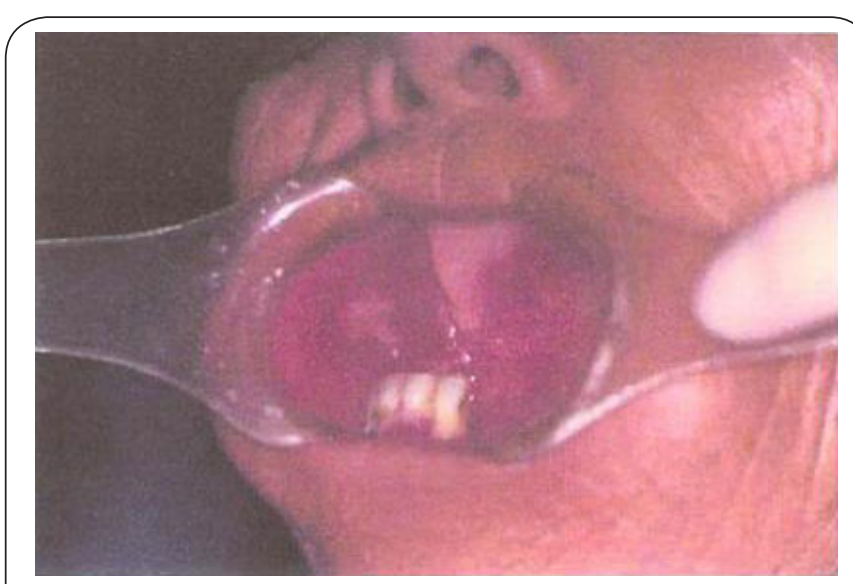

Figure 1. A macroscopic view of human oral leukoplakia. 
Watanabe et al. Oncology Discovery 2015,

\section{Erythroplakia}

Another condition that often is misunderstood is the clinicopathological entity described as erythroplakia (Figure 2). Erythroplakia refers to a concept similar to leukoplakia, except in this case, the clinician is dealing with red patches that cannot be described as any other entity or attributed to a traumatic etiology. Once inflammatory or traumatic lesions are excluded, one is left with a true erythroplakia. This is a critical distinction, because almost all erythroplakias are precancerous or cancerous conditions. Incredibly, a definitive study on erythroplakias reported that $90 \%$ represented carcinoma, carcinoma in situ (CIS) or severe dysplasia [32]. The epithelium is often attenuated, and as one would expect in the sites most frequently affected, usually shows minimal keratinization. These histopathological alterations contribute greatly to the clinical appearance of thee lesion.

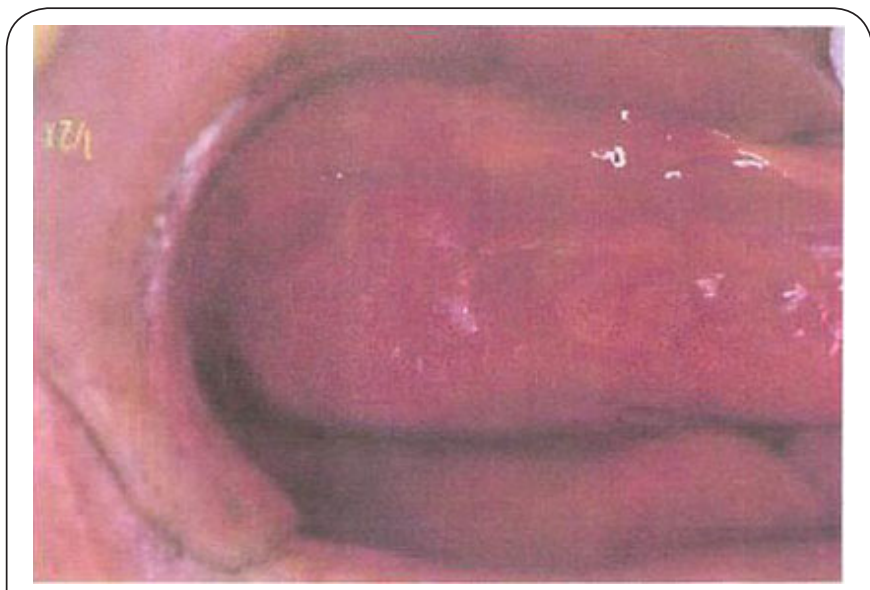

Figure 2. A macroscopic view of human oral erythroplakia.

\section{Epithelial dysplasia}

Epithelial dysplasia (Figure 3 ) is generally considered to be a histopathological diagnostic term. Standard carcinogenic theory portrays SCCs as progressing through stages of premalignancy before actual invasion. The progression would proceed through epithelial dysplasia and CIS, ultimately culminating in SCC. This is no doubt that this is true in many instances. However, it has been shown that cases of epithelial dysplasia may remain static or even regress, whereas examples of SCC have been shown to arise de novo [33]. Because of this, epithelial dysplasia develops approximately three times more frequently in the patient population than SCC. However, epithelial dysplasia represents a premalignant lesion that should be treated as if it will progress to carcinoma. The histological and cytological features of epithelial dysplasia are shown in Table 4.

The diagnosis of dysplasia generally entails the findings of at least two of the items within the group of histological features. It should be understood that many of these criteria alone are not pathognomotic for dysplasia, but the presence

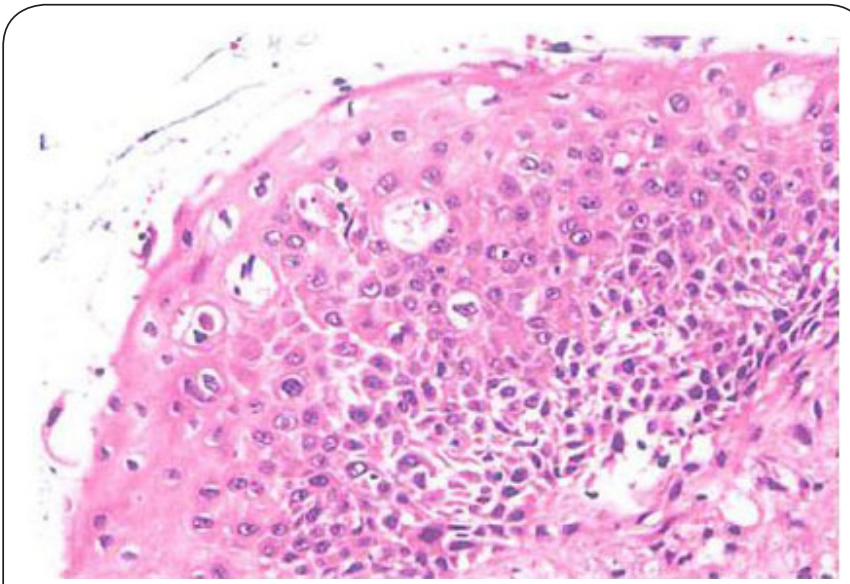

Figure 3. The histological features of oral dysplasia (moderate squamous cell dysplasia).

Table 4. The histopathological features of oral squamous dysplasia.

\begin{tabular}{|c|c|}
\hline \multirow[t]{3}{*}{ Morphological features } & Bulbous, teardrop-shaped rete ridges \\
\hline & Loss of polarization and orientation \\
\hline & Exaggerated intercellular spacing \\
\hline \multirow[t]{4}{*}{ Cytological features } & $\begin{array}{l}\text { Increased nuclear/cytoplasmic (N/C) } \\
\text { ratio }\end{array}$ \\
\hline & Nuclear hyperchromasia \\
\hline & $\begin{array}{l}\text { Nuclear polymorphisms with prominent } \\
\text { nucleoli }\end{array}$ \\
\hline & Excessive or abnormal mitotic figures \\
\hline
\end{tabular}

of several of these factors leads to the diagnosis. Dysplasia is graded as mild, moderate or severe (Table 5). These grades are somewhat subjective, although inter-observer rates of over $90 \%$ agreement have been reported by some authors [34]. The separations depend on the extent of epithelial involvement. When the lowest quarter of the epithelium exhibits dysplastic features, a diagnosis of mild dysplasia is rendered. When half of the thickness is involved, moderate dysplasia is the appropriate term. If three-fourths of the epithelium shows the alterations described, the term severe epithelial dysplasia is used. Dysplastic lesions undergo transformation into malignancy over time. It has been reported that malignant transformation was observed in $10.4 \%$, and the rate of first recurrence after laser surgery was approximately 19.5\% [35]. The rate of recurrence had significant association with the severity of epithelial dysplasia [35]. Recurrence and malignant transformation was mainly identified in erythroplakias and non-homogenous leukoplakias [35].

\section{Oral neoplasms \\ Squamous cell papilloma}

Squamous cell papilloma, a benign epithelial neoplasm, is the most common focal papillary lesion of the oral mucosa [36]. The lesion may be pedunculated or sessile, and may be normal 
Watanabe et al. Oncology Discovery 2015,

http://www.hoajonline.com/journals/pdf/2052-6199-3-1.pdf

Table 5. The WHO classification of oral squamous dysplasia and CIS.

\begin{tabular}{|c|c|c|c|}
\hline $\begin{array}{l}2005 \text { WHO } \\
\text { classification }\end{array}$ & $\begin{array}{l}\text { Squamous } \\
\text { intraepithelial } \\
\text { neoplasia (SIN) }\end{array}$ & Grade & $\begin{array}{l}\text { Oral } \\
\text { cytology }\end{array}$ \\
\hline Mild dysplasia & SIN1 & \multirow{2}{*}{$\begin{array}{l}\text { Low grade } \\
\text { dysplasia }\end{array}$} & \multirow{2}{*}{$\begin{array}{l}\text { Low grade } \\
\text { SIN }\end{array}$} \\
\hline Moderate dysplasia & SIN2 & & \\
\hline Severe dysplasia & SIN3 & \multirow{2}{*}{$\begin{array}{l}\text { High grade } \\
\text { dysplasia }\end{array}$} & \multirow{2}{*}{$\begin{array}{l}\text { High grade } \\
\text { SIN }\end{array}$} \\
\hline $\begin{array}{l}\text { Carcinoma in situ } \\
\text { (CIS) }\end{array}$ & SIN3 & & \\
\hline
\end{tabular}

in color or white. It is exophytic with multiple blunt ended projections, giving rise to a pebbly, cobblestone appearance. The sites involved include the palate, tongue, lips and gingival [7]. The etiology is unclear, but human papillomaviruses (HPVs, strains 6 and 11 are found most commonly) can be demonstrated in up to $15 \%$ of lesions $[11,16]$. Histologically, the lesions are finger-like processes of proliferating stratified squamous epithelium supported by thin cores of vascular connective tissue. The neoplastic epithelial covering may show hyperkeratosis. Mitotic figures are often seen in the basal layer of the epithelium, but features of epithelial dysplasia and malignancy are not present. Malignant changes have not been described in a squamous cell papilloma of the oral mucosa and it is not considered to be a premalignant lesion.

\section{Carcinoma in situ (CIS)}

$\mathrm{CIS}$ represents an intraepithelial malignancy, and invasion is considered to be imminent (Figure 4). Most of the same features found in epithelial dysplasia are seen in $\mathrm{CIS}$, however, invasion and keratin pearl formation are not seen in CIS. Histopathologically, cancer cells with an increased number of mitoses, including abnormal mitosis, nuclear atypism and loss of polarity are found in CIS, similar to CIS lesions of the uterine cervix [37]. Oral CIS usually presents clinically as leukoplakia or erythroplakia. The lesion may progress with time to invasive carcinoma. It is not uncommon to find histological changes of CIS in the epithelium surrounding an invasive carcinoma, which might suggest a field change in a wide area of the mucosa. Some carcinomas thought to be recurrent probably represent new primary lesions arising in such a changed field.

\section{Squamous cell carcinoma (SCC)}

There is considerable variation in the histological appearances of oral SCCs, although all show invasion and destruction of the surrounding tissue (Figure 5). In the well-differentiated type, the neoplastic cells are obviously squamous in type and consist of masses of prickle cells with a limiting layer of basal cells around the periphery. Intercellular bridges are readily recognizable. Keratin pearls are often found within the masses of infiltrating neoplastic cells, with each pearl consisting of a central area of keratin surrounded by whorls

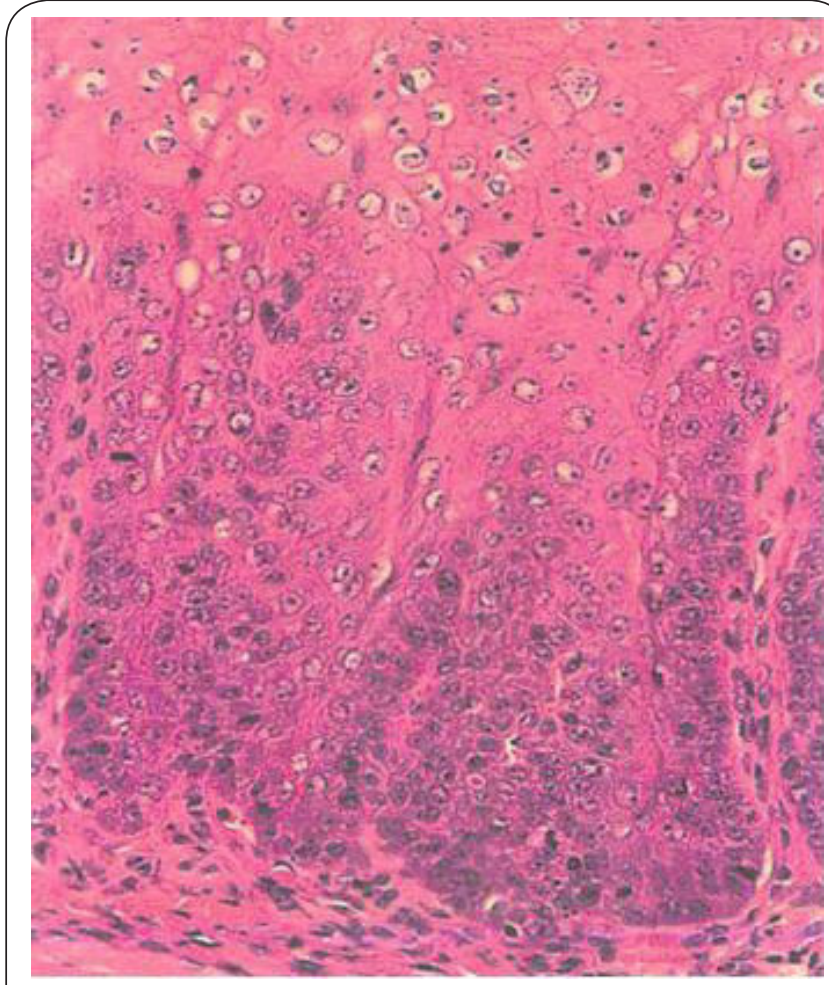

Figure 4. The histological features of human oral squamous cell carcinoma in situ.
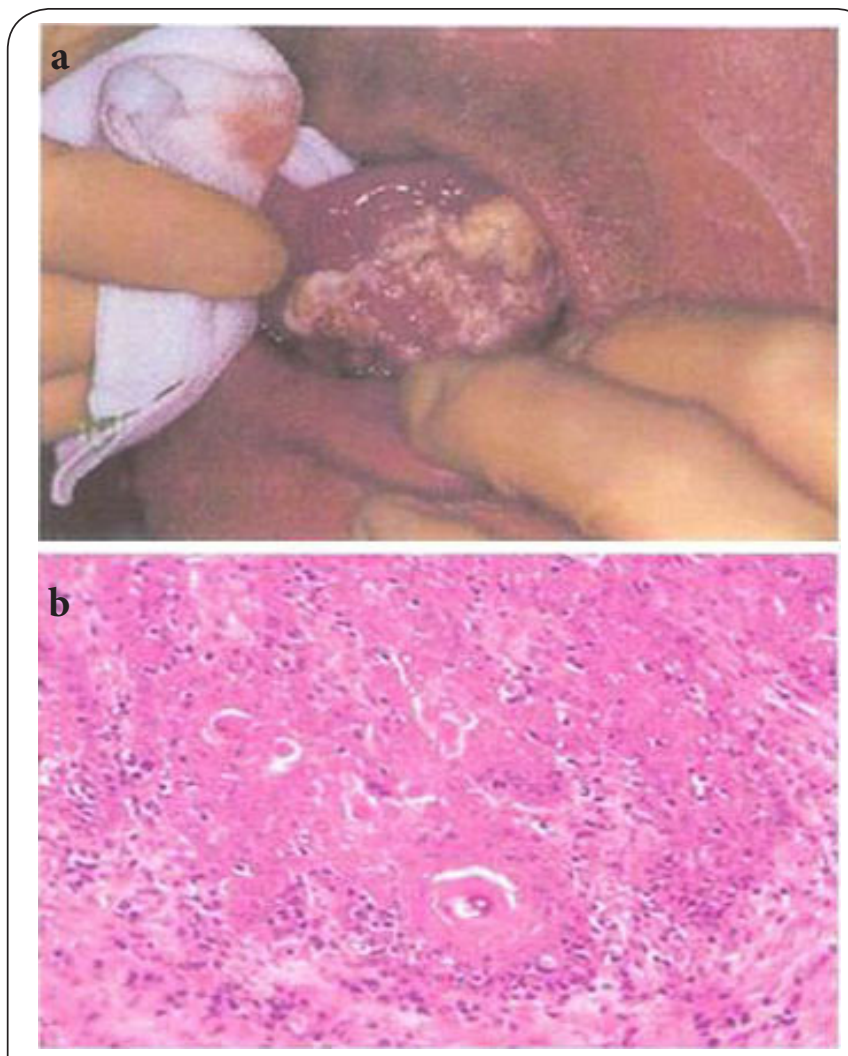

Figure 5. A macroscopic view (a) the histological findings (b) of invasive squamous cell carcinoma in the human oral cavity. 
Watanabe et al. Oncology Discovery 2015,

of prickle cells. In less well-differentiated tumors, the keratin pearls are sparse or absent, and the prickle cells and their nuclei are much more pleomorphic. Mitotic figures are usually abundant, and many may be atypical.

In poorly differentiated or anaplastic types of tumors, the neoplastic cells are even more irregular and may hardly be recognizable as being of epithelial origin. In such cases, immunohistochemical staining to demonstrate the cytokeratin expression (intermediate filament proteins that characterize epithelial cells) is particularly valuable for the diagnosis. Most oral SCCs are extremely locally destructive. Lymphatic permeation, vascular invasion, sarcolemmal spread and perineural spread may also occur. Invasion of bone can also occur as a result of local spread. Lymphatic spread to the regional lymph nodes is a variable feature, but the frequency of cervical metastasis tends to increase with an increasing size of the primary tumor. Blood-borne metastases occur late in the clinical course of the disease, but many patients die before distant metastases become apparent.

\section{Early detection}

For large-scale screening, certain dye materials may help to identify abnormal mucosa, which can attract the oral examiners attention. Toluidine blue has been championed for several decades worldwide as a means of identifying clinically occult lesions in patients [38]. The efficacy of this technique has been evaluated in many reports with diverse results. It has yielded sensitivities between $72 \%$ and $100 \%$ and specificities between $45 \%$ and $67 \%$ for detecting suspicious malignancies [39]. However, the material data safety sheet indicates that toluidine blue is probably toxic by ingestion, and it is seldom used in detecting cancers in other tissues. An acidic dye, methylene blue, is another recently proposed dye used for in vivo staining during endoscopic examinations $[40,41]$. Methylene blue binds to the double helical DNA with high affinity. The methylene blue staining thus increases in intensity, with an increase in chromatin material in premalignant and malignant cells.

\section{Animal models of oral carcinogenesis}

Great effort have been made to establish a more realistic animal model of oral carcinogenesis which has histological, immunological, and molecular characteristics similar to the human counterparts. There are currently two animal models, a hamster buccal pouch carcinogenesis model and a rat tongue carcinogenesis model, that have been used to understand the pathogenesis of oral cancer. The hamster model, which uses the hamster buccal pouch and topical application of a chemical carcinogen, 7,12-dimethylbenz(a)anthracene (DMBA), was first reported by Salley [42] in 1954, and has turned out to be an optimal model for studying oral cancer [43]. In this model, SCCs develop slowly from an initial precancerous lesion similar to human leukoplakia with a dysplastic nature [44]. The malignancies gradually become invasive and have the potential to metastasize to regional (cervical) lymph nodes. The neoplasms resemble their human counterparts both grossly and microscopically [43], and have similar metabolic markers [45], including $\gamma$-glutamyl transpeptidase [46], polyamines and ornithine decarboxylase [47].

The initiation and promotion of the neoplasms could be demonstrated in the model [48]. Chronic irritation and/ or inflammation in the mouth, which is a risk factor for the development of human oral cancer enhances buccal carcinogenesis in this model, and is induced using a potent mucosal irritant, croton oil [49]. Oncogenes expressed in the resulting hamster pouch carcinomas have been found to include c-erb-B [50], c-Ha-ras [51,52], Ki-ras [50] and mutant $p 53$ [53]. A new putative oral cancer suppressor gene (doc-1) was found in a study of hamster buccal pouch carcinogenesis, and a human counterpart of this gene was subsequently found, cloned and mapped [54]. Thus, studies on the molecular biology and molecular genetics in the experimental pathology of oral cancer in the hamster buccal pouch have led to an increased understanding of the molecular mechanisms underlying the development of human oral cancer $[55,56]$.

Although this model has many similarities to human oral cancer development, it also has differences compared to the human presentation of oral cancer. These include the delayed movement of molecules and tumor cells into and out of the buccal pouch, a low number of cytotoxic $T$ cell lymphocytes with restricted antigen recognition sites and a lack of an anatomic pouch in the human [57].

The rat tongue mucosa SCC induced by the oral administration of 4-nitroquinoline 1-oxide (4-NQO) in drinking water

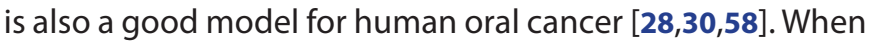
$20 \mathrm{ppm}$ 4-NQO in drinking water was administered orally to rats for eight weeks, followed by the administration of normal tap water without 4-NQO for 24 weeks, gross changes including leukoplakia, erosions, ulcers and papillary tumors on the dorsum of the posterior tongue developed (Figure 6). Their corresponding histopathological findings ranged from hyperplasia to dysplasia with various degrees of atypia to SCC (CIS and well-differentiated invasive carcinoma) [58]. The severity of the lesions corresponded to the duration of the 4-NQO administration. The tongues in rats treated with 4-NQO for eight weeks have an $\sim 80-100 \%$ incidence of hyperplasia and a $20 \%$ incidence of mild and moderate dysplasia (Figure 7); those treated for 12 weeks have a nearly $70 \%$ incidence of mild and moderate dysplasia and around $35 \%$ incidence of severe dysplasia (Figure 8). Those treated for 16 weeks have a nearly $60 \%$ incidence of severe dysplasia and a $45 \%$ inciudence of CIS (Figure 9) and those treated for 32 weeks have an about $80 \%$ incidence of severe dysplasia, a nearly $15 \%$ incidence of CIS and a 50-70\% incidence of invasive SCC (Figure 9). A few squamous cell papillomas (Figure 10) also develop in the tongues of rats treated with 4-NQO. In our unpublished work, the incidence of tongue cancer in rats treated with 4-NQO for eight weeks, 12 weeks and 16 weeks and then observed for 32 


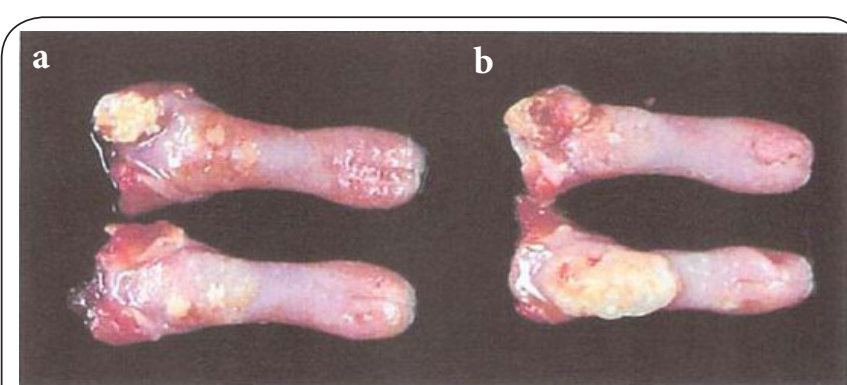

Figure 6. Representative images of normal tongues (a) tongue lesions and (b) induced by 4-NQO treatment in rats.
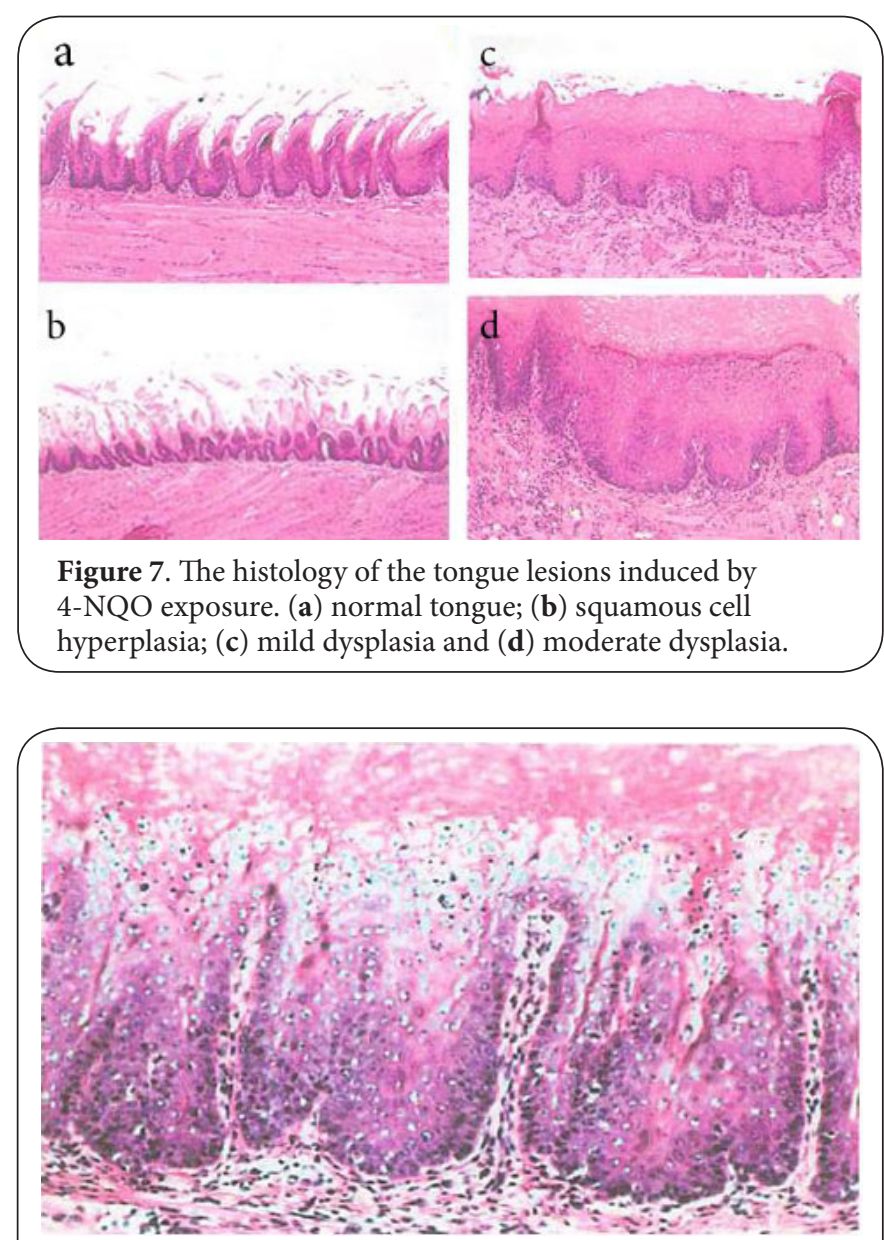

Figure 8. The histology of severe squamous cell dysplasia of the tongue in a rat treated with 4 -NQO.

weeks was $50 \%, 65 \%$ and $80 \%$, respectively. Metastasis was rarely found. Thus, 4-NQO reliably produces preneoplastic and neoplastic tongue mucosal lesions, which morphologically and histologically mimic human oral carcinogenesis. The rat tongue, a target organ of 4-NQO, is not an immunologically privileged site like the hamster buccal pouch. Thus, the model should be more appropriate to study the molecular mechanism(s) of neoplastic transformation and to assess new treatment modalities for premalignant and malignant
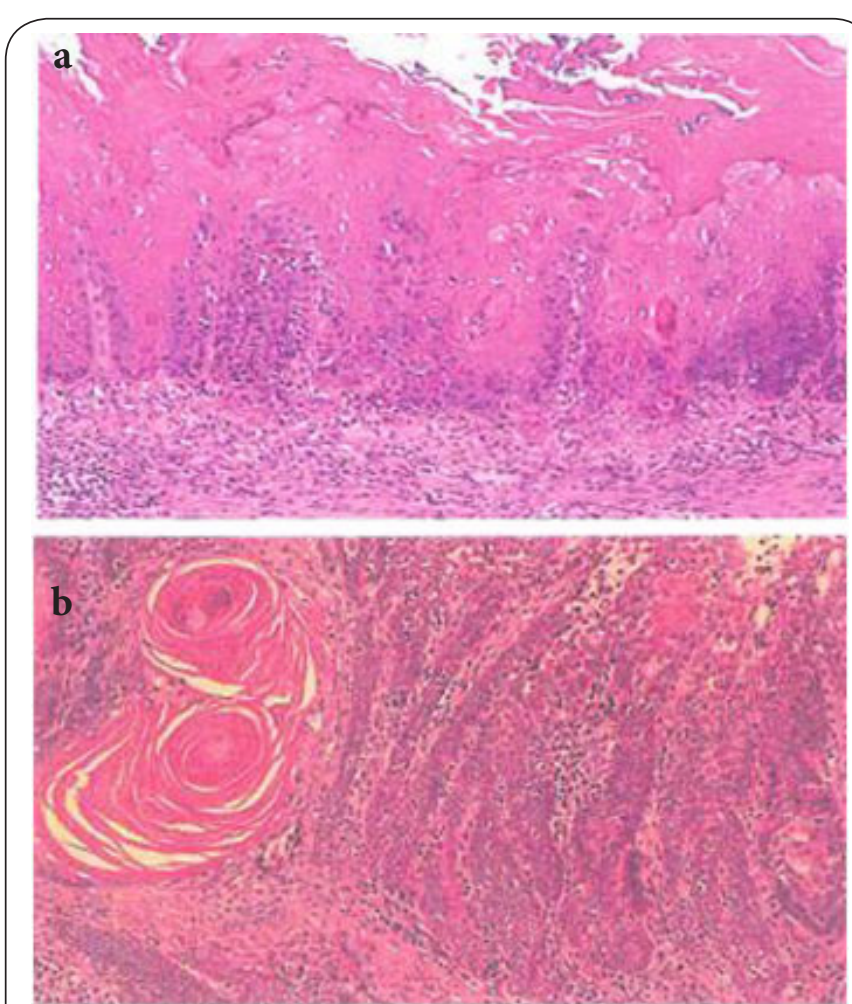

Figure 9. The histology of tongue (a) squamous cell carcinoma in situ and (b) invasive squamous cell carcinoma in rats treated with 4-NQO.

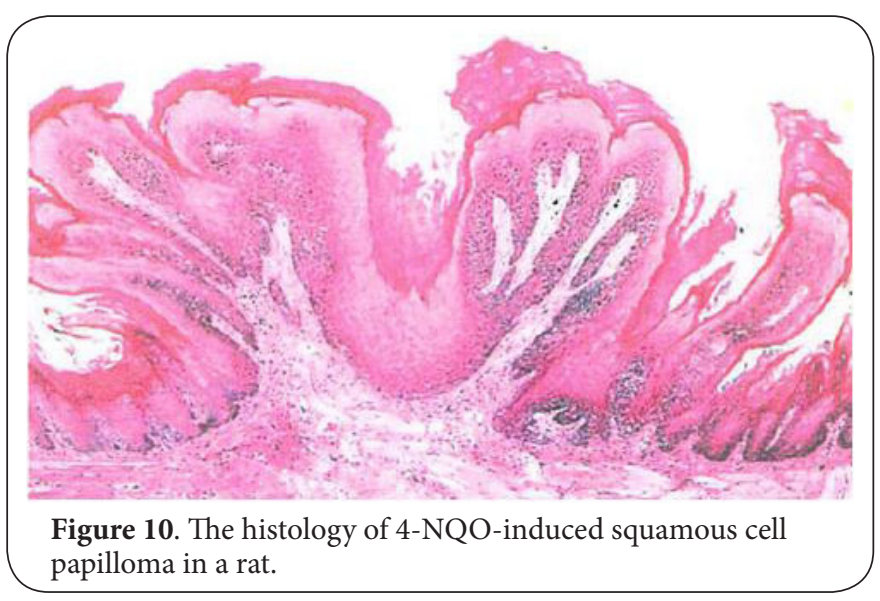

lesions of the human oral cavity.

We previously suggested that severe dysplasia is a direct precursor lesion for SCC of the tongue induced by 4-NQO [58]. Although molecular alterations are infrequent in 4-NQOinduced rat tongue carcinomas $[59,60]$, our recent study has revealed that 4-NQO treatment for eight weeks could more rapidly induce (within eight weeks) tongue dysplasia, squamous cell papillomas and squamous cell carcinoama in male and female transgenic rats carrying the human c-Ha-ras proto-oncogene [61], when compared to wild rats, suggesting that alterations of c-Ha-ras are involved in 4-NQO- 
Watanabe et al. Oncology Discovery 2015,

induced tongue carcinogenesis, especially the early phase of carcinogenesis. Interestingly, this transgenic rat also develops taste bud tumors $[6 \mathbf{6 2}, \mathbf{6 3}]$.

Despite widening interest in the possible association between inflammation and cancer development, the knowledge of this issue in relation to oral cancer is still limited. We have recently determined the susceptibility of Apc-mutant Kyoto Apc Delta (KAD) rats, which are vulnerable to developing inflammation-associated colorectal carcinogenesis [64-67], to 4-NQO-induced tongue carcinogenesis in order to clarify the role of inflammation in oral cancer [68]. KAD (20 males and 22 females) and F344/NS1c (22 males and 23 females) rats received drinking water with or without 4-NQO (20 ppm) for eight weeks. At week 20, tongue SCC developed in both the KAD and F344/NS1c rats that received 4-NQO. Regardless of gender, the incidence and multiplicity of tongue SCC were greater in the KAD rats than in the F344/NS1 c rats. In addition, the multiplicity of tongue SCC in the female KAD rats was significantly greater than that observed in the male KAD $(p<0.01)$ and female F344/NS1c rats $(p<0.05)$. The levels of inflammation and the mRNA expression of inflammatory cytokines in the tongue in the 4-NQO-treated female KAD rats were the highest among the rats given 4-NQO. Therefore, KAD rats, particularly females, are susceptible to 4-NQO-induced tongue carcinogenesis, thus suggesting the utility of models employing KAD rats for investigating the pathobiology of oral (tongue) carcinogenesis associated with inflammation.

Type 2 diabetes mellitus and malignant tumors are common diseases worldwide. The incidence of these two diseases continues to increase, and they both cause serious health care problems. Population-based epidemiological studies have shown that the co-existence of type 2 diabetes and malignant tumors is more frequent than expected based on the age-corrected incidence and prevalence of each disease. Epidemiological studies and meta-analyses showed that type 2 diabetes increases the risk and tumor specific mortality from certain cancers [69]. The overlapping risk factors for the diseases suggests that there is a relationship between type 2 diabetes and malignant tumors, with a significant role of obesity as a major risk factor [70]. In the pathophysiology of type 2 diabetes there are several biological processes which may explain the higher cancer risk. The mitotic effects of hyperinsulinemia likely play an important role in the relationship between cancer and type 2 diabetes mellitus. Betel quid chewing, known to be a risk factor for oral cancer and esophageal cancer, is associated with an increased risk of metabolic disease, cardiovascular disease and all-cause mortality [71]. To investigate the association between diabetes/obesity and oral cancer development, we have determined the susceptibility of Tsumura Suzuki obese diabetes (TSOD) mice, which spontaneously develop diabetes mellitus, obesity, glucosuria, hyperglycemia and hyperinsulinemia, to 4-NQO-induced tongue carcinogenesis. Both male and female TSOD mice developed many more 4-NQO-induced tongue and esophageal
SCCs compared to the control TSNO mice (unpublished work).

\section{Molecular carcinogenesis}

The etiological role of tobacco in the development of oral cancer is well accepted. Nevertheless, the incidence of oral cancer is relatively low compared to the large number of individuals exposed to tobacco carcinogens, suggesting that host genetic factors must affect the individual disease susceptibility. Oral squamous carcinogenesis is a multistep process in which multiple genetic events occur that alter the normal functions of oncogenes and tumor suppressor genes. Oral cancer arises following six to 10 independent genetic events [72]. This can result in the increased production of growth factors or in the numbers of cell surface receptors, enhanced intracellular messenger signaling, and/or increased production of transcription factors. In combination with the loss of tumor suppressor activities, this leads to a cell phenotype capable of increased cell proliferation, with a loss of cell cohesion and the ability of the cells to infiltrate surrounding tissues and spread to distant sites. Knowledge of the putative genes involved in oral cancer may provide a greater understanding of the biological diversity of the cancer. Some of the most important components of the multistep oral carcinogenesis process may be the accumulation of genetic changes reflecting the degree of carcinogen exposure, the inherent sensitivity of the individual and the degree of tissue damage. The cells with specific hits at the premalignant stages may be more likely to progress towards malignancy. At the genetic level, oncogenes and tumor suppressor genes are the two interacting classes of genes forming the two sides of a coin, both of which play a critical role in the pathobiology of oral cancer [73].

Again, cancer evolves via a series of distinct steps, each characterized by the sequential accumulation of additional genetic defects, followed by clonal expansion [74]. Consequently, it is possible to define a genetic progression model of this disease. In this regard, the pioneering work characterizing the genetic alterations in colorectal cancer has now become a paradigm for other human neoplasias [75]. The model describes a stepwise involvement of important cancer genes during the various stages of tumor progression. It is now believed that oral SCC follows a similar pattern in its development, and thus, malignancy may be preceded by premalignant lesions such as leukoplakia, erythroplakia, etc. [76]. The precise nature of the genetic alterations occurring at each step is still unclear, but a recent report has described a preliminary molecular progression model of head and neck cancer, including oral cancer [77]. In this tumor type, the genetic lesions occur in a distinct order of events (Figure 11). For instance, the loss of chromosomal material is thought to result in changes leading to dysplasia (9p21, 3p21, 17p13), CIS $(11 g 13,13 g 21,14 g 31)$ and invasive tumors (4q26-28, 6p, $8 p, 8 q)$. Although the available information is still limited, it nevertheless provides a framework for understanding the 


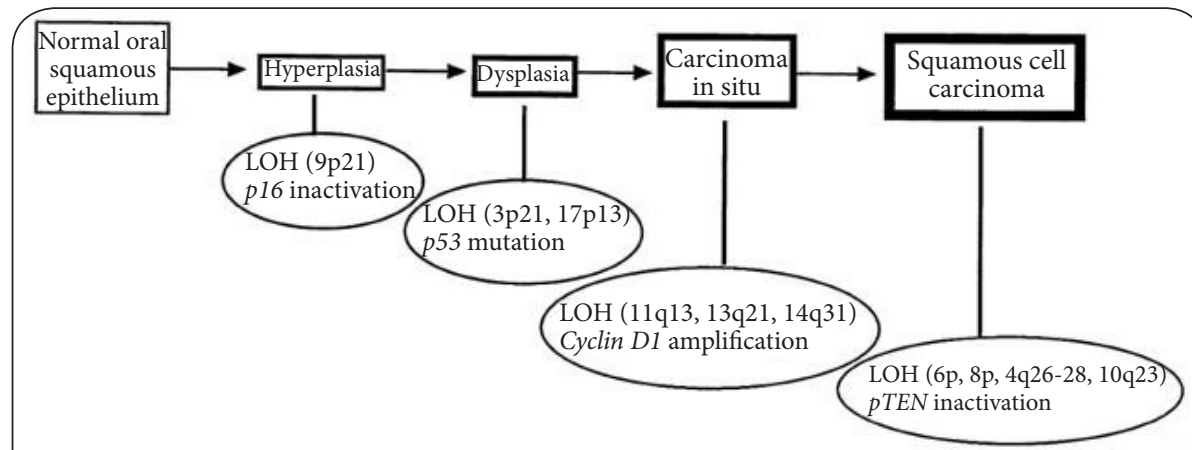

Figure 11. The histopathological and molecular progression of oral carcinoma.

molecular pathogenesis of this type of cancer.

\section{Chemoprevention}

The findings of genetic alterations in defined premalignant lesions, as well as in the non-malignant epithelium, have indicated that oral carcinogenesis is a multistep process associated with the accumulation of genetic insults over time $[\mathbf{2 8 , 3 0 , 7 8 ]}$. Given the readily accessible means for objectively assessing premalignant lesions in the oral cavity, the concept of chemoprevention, whereby the use of a pharmacological or natural agent is intended to halt this process, has been an attractive topic in oral SCC. Since oral cancer is an aggressive malignancy, more work is needed to improve our understanding of the natural history of the disease and to identify key molecular alterations that render transformation irreversible. Over the past few decades, many chemopreventive agents have been studied for cancers in a variety of tissues, including the oral cavity $[\mathbf{2 8 , 3 0 , 7 8 - 8 1 ] . ~}$ Candidate agents include retinoids, cyclooxygenase inhibitors, green tea polyphenols, $p 53$-targeted agents, thiazolidinediones and epidermal growth factor receptor (EGFR) inhibitors have all been evaluated $[\mathbf{8 0}, \mathbf{8 1}]$. We are currently in a new era of chemoprevention employing novel trial designs and agents, focusing on molecularly-defined high-risk populations, and supported by improved pre-clinical animal models.

As mentioned above, chronic inflammation is integrally related to oxidative stress, and has been increasingly recognized as a contributing factor in various chronic diseases, including cancer and metabolic syndrome. Thus, inhibiting this vicious cycle has the potential to delay, prevent the progression of and/or treat these diseases. However, the adverse effects of the current anti-inflammatory drugs [82,83] and the failure of exogenous antioxidant administration [29] should encourage scientists to develop new therapeutic alternatives.

\section{Conclusion}

Oral SCCs continue to be a group of diseases with high mortality and increasing incidence rates, particularly among young individuals. These may be a paradoxical findings, because most oral cancers are preceded (by up to seven years) by readily detectable mucosal changes, most often leukoplakia and eryhthroplakia. The prevalence of oral leukoplakia or erythroplakia differs worldwide, and only a fraction of these lesions are related to cancer development, but they do provide a prompt for clinicians to more closely monitor the patient for the progression of the lesion. Tobacco and alcohol remain the primary factors associated with the etiology of oral cancer and precancerous lesions. Other risk factors associated with oral SCC include marijuana use, betel quid use, nutritional factors, race, socioeconomic status, sunlight exposure, age, HPV infection, immunosuppression and genetic mutations. The current focus should be on identifying the high-risk lesions and making a risk assessment using various risk factors proposed based on the use of the appropriate animal models. In addition, recently published data have pointed to genomic aberrations as an indicator for targeting patients at particular risk for future cancerous lesions in the oral cavity. Of course, primary, secondary or tertiary prevention might be useful for the prevention of oral precancerous lesions and carcinomas $[78,84]$. Coupled with cancer-preventive measures, the growing understanding of the mechanism of oral carcinogenesis could result in improved treatment strategies and reduced oral cancer mortality. There is an urgent need to differentiate potentially malignant lesions that will truly progress to malignancy from preneoplasia and/or preneoplastic conditions. A thorough understanding of the biology of oral preneoplastic lesions, as, based on better technology and new information, will help in combating this malignancy.

\section{Competing interests}

The authors declare that they have no competing interests.

Authors' contributions

\begin{tabular}{|l|c|c|c|c|}
\hline Authors' contributions & NW & TO & MS & TT \\
\hline Research concept and design & $\checkmark$ & -- & $\checkmark$ & $\checkmark$ \\
\hline Collection and/or assembly of data & -- & $\checkmark$ & -- & -- \\
\hline Data analysis and interpretation & -- & $\checkmark$ & -- & -- \\
\hline Writing the article & $\checkmark$ & $\checkmark$ & $\checkmark$ & $\checkmark$ \\
\hline Critical revision of the article & $\checkmark$ & -- & -- & $\checkmark$ \\
\hline Final approval of article & $\checkmark$ & $\checkmark$ & $\checkmark$ & $\checkmark$ \\
\hline
\end{tabular}

\section{Acknowledgement}

This work was supported in part by Grant-in-Aid for the $3^{\text {rd }}$ Term Comprehensive 10-Year Strategy for Cancer Control from the 
Watanabe et al. Oncology Discovery 2015,

Ministry of Health, Labor and Welfare of Japan.

Publication history

EIC: Paul J. Higgins, Albany Medical College, USA.

Received: 17-Feb-2015 Final Revised: 24-Mar-2015

Accepted: 03-Apr-2015 Published: 09-Apr-2015

\section{References}

1. Parkin DM, Pisani P and Ferlay J. Estimates of the worldwide incidence of eighteen major cancers in 1985. Int J Cancer. 1993; 54:594-606. | Article I PubMed

2. Johnson NW. Orofacial neoplasms: global epidemiology, risk factors and recommendations for research. Int Dent J. 1991; 41:365-75. | Article | PubMed

3. Parkin DM, Laara E and Muir CS. Estimates of the worldwide frequency of sixteen major cancers in 1980. Int J Cancer. 1988; 41:184-97. | Article I PubMed

4. Boring CC, Squires TS and Tong T. Cancer statistics, 1992. CA Cancer J Clin. 1992; 42:19-38. | Article | PubMed

5. Johnson NW and Warnakulasuriya KA. Epidemiology and aetiology of oral cancer in the United Kingdom. Community Dent Health. 1993; 10 Suppl 1:13-29. I PubMed

6. Macfarlane GJ, Boyle P, Evstifeeva TV, Robertson C and Scully C. Rising trends of oral cancer mortality among males worldwide: the return of an old public health problem. Cancer Causes Control. 1994; 5:259-65. | Article | PubMed

7. Neville BW and Day TA. Oral cancer and precancerous lesions. CA Cancer J Clin. 2002; 52:195-215. I Article I PubMed

8. Krishna Rao SV, Mejia G, Roberts-Thomson K and Logan R. Epidemiology of oral cancer in Asia in the past decade--an update (2000-2012). Asian Pac J Cancer Prev. 2013; 14:5567-77. | Article I PubMed

9. Sand $L$ and Jalouli J. Viruses and oral cancer. Is there a link? Microbes Infect. 2014; 16:371-8. | Article | PubMed

10. Turi K, Barabas P, Csurgay K, Lehner GY, Lorincz A and Nemeth ZS. An analysis of the epidemiological and etiological factors of oral tumors of young adults in a Central-Eastern European population. Pathol Oncol Res. 2013; 19:353-63. I Article I PubMed

11. Garlick JA and Taichman LB. Human papillomavirus infection of the oral mucosa. Am J Dermatopathol. 1991; 13:386-95. | PubMed

12. Regezi JA, Greenspan D, Greenspan JS, Wong E and MacPhail LA. HPVassociated epithelial atypia in oral warts in HIV+ patients. J Cutan Pathol. 1994; 21:217-23. | Article | PubMed

13. Eisenberg E, Rosenberg B and Krutchkoff DJ. Verrucous carcinoma: a possible viral pathogenesis. Oral Surg Oral Med Oral Pathol. 1985; 59:52-7. I Article I PubMed

14. Mork J, Lie AK, Glattre E, Hallmans G, Jellum E, Koskela P, Moller B, Pukkala E, Schiller JT, Youngman L, Lehtinen M and Dillner J. Human papillomavirus infection as a risk factor for squamous-cell carcinoma of the head and neck. N Engl J Med. 2001; 344:1125-31. N Engl J Med 2001, 344:1125-1131. | Article | PubMed

15. Woods KV, Shillitoe EJ, Spitz MR, Schantz SP and Adler-Storthz K. Analysis of human papillomavirus DNA in oral squamous cell carcinomas. J Oral Pathol Med. 1993; 22:101-8. I Article I PubMed

16. Bouda M, Gorgoulis VG, Kastrinakis NG, Giannoudis A, Tsoli E, DanassiAfentaki D, Foukas P, Kyroudi A, Laskaris G, Herrington CS and Kittas C. "High risk" HPV types are frequently detected in potentially malignant and malignant oral lesions, but not in normal oral mucosa. Mod Pathol. 2000; 13:644-53. | Article | PubMed

17. El-Mofty SK and Lu DW. Prevalence of human papillomavirus type 16 DNA in squamous cell carcinoma of the palatine tonsil, and not the oral cavity, in young patients: a distinct clinicopathologic and molecular disease entity. Am J Surg Pathol. 2003; 27:1463-70. | Article I PubMed

18. Wilczynski SP, Lin BT, Xie Y and Paz IB. Detection of human papillomavirus DNA and oncoprotein overexpression are associated with distinct morphological patterns of tonsillar squamous cell carcinoma. Am J Pathol. 1998; 152:145-56. | PubMed Abstract | PubMed Full Text

19. Klussmann JP, Gultekin E, Weissenborn SJ, Wieland U, Dries V, Dienes HP, Eckel HE, Pfister HJ and Fuchs PG. Expression of p16 protein identifies a distinct entity of tonsillar carcinomas associated with human papillomavirus. Am J Pathol. 2003; 162:747-53. I Article I PubMed Abstract | PubMed Full Text

20. Gillison ML, Koch WM, Capone RB, Spafford M, Westra WH, Wu L, Zahurak ML, Daniel RW, Viglione M, Symer DE, Shah KV and Sidransky D. Evidence for a causal association between human papillomavirus and a subset of head and neck cancers. J Natl Cancer Inst. 2000; 92:709-20. | Article I PubMed

21. McRee AL, Reiter PL, Chantala K and Brewer NT. Does framing human papillomavirus vaccine as preventing cancer in men increase vaccine acceptability? Cancer Epidemiol Biomarkers Prev. 2010; 19:1937-44. I Article | PubMed Abstract | PubMed Full Text

22. Slaughter DP, Southwick HW and Smejkal W. Field cancerization in oral stratified squamous epithelium; clinical implications of multicentric origin. Cancer. 1953; 6:963-8. I Article I PubMed

23. Thomson PJ. Field change and oral cancer: new evidence for widespread carcinogenesis? Int J Oral Maxillofac Surg. 2002; 31:262-6. | Article | PubMed

24. Wright JM. Oral precancerous lesions and conditions. Semin Dermatol. 1994; 13:125-31. | Article I PubMed

25. Speight PM, Farthing $P$ and Bouquot JE. The pathology of oral cancer and precancer. Curr. Diag. Pathol. 1996; 3:165-176. | Article

26. Monteil RA. [Oral leukoplakia: clinical or histologic entity?]. Ann Pathol. 1983; 3:257-61. | Article | PubMed

27. Mikhail GR. Cancers, precancers, and pseudocancers on the male genitalia. A review of clinical appearances, histopathology, and management. J Dermatol Surg Oncol. 1980; 6:1027-35. | Article | PubMed

28. Tanaka $T$ and Ishigamori R. Understanding carcinogenesis for fighting oral cancer. J Oncol. 2011; 2011:603740. | Article | PubMed Abstract | PubMed Full Text

29. Tanaka T,Shnimizu M and Moriwaki H. Cancer chemoprevention by carotenoids. Molecules. 2012; 17:3202-42. | Article | PubMed

30. Tanaka $T$ and Tanaka M. Oral carcinogenesis and oral cancer chemoprevention: a review. Patholog Res Int. 2011; 2011:431246. | Article | PubMed Abstract | PubMed Full Text

31. Waldron CA and Shafer WG. Leukoplakia revisited. A clinicopathologic study 3256 oral leukoplakias. Cancer. 1975; 36:1386-92. | Article | PubMed

32. Shafer WG and Waldron CA. Erythroplakia of the oral cavity. Cancer. 1975; 36:1021-8. | Article | PubMed

33. Crissman JD and Zarbo RJ. Dysplasia, in situ carcinoma, and progression to invasive squamous cell carcinoma of the upper aerodigestive tract. Am J Surg Pathol. 1989; 13 Suppl 1:5-16. | Article I PubMed

34. Lippman SM, Batsakis JG, Toth BB, Weber RS, Lee JJ, Martin JW, Hays $\mathrm{GL}$, Goepfert $\mathrm{H}$ and Hong WK. Comparison of low-dose isotretinoin with beta carotene to prevent oral carcinogenesis. N Engl J Med. 1993; 328:15-20. | Article | PubMed

35. Jerjes W, Upile T, Hamdoon Z, Al-Khawalde M, Morcos M, Mosse CA and Hopper C. CO2 laser of oral dysplasia: clinicopathological features of recurrence and malignant transformation. Lasers Med Sci. 2012; 27:16979. | Article | PubMed

36. Firth NA. Oral lesions with a papillary surface texture: clinical and pathological correlations. Ann R Australas Coll Dent Surg. 2000; 15:1115. | Article | PubMed

37. Tanaka T. Proliferative activity in dysplasia, carcinoma in situ and microinvasive carcinoma of the uterine cervix. Pathol Res Pract. 1986; 181:531-9. | Article | PubMed

38. Mashberg A. Final evaluation of tolonium chloride rinse for screening of high-risk patients with asymptomatic squamous carcinoma. J Am Dent Assoc. 1983; 106:319-23. | Article | PubMed

39. Onofre MA, Sposto MR and Navarro CM. Reliability of toluidine blue 
Watanabe et al. Oncology Discovery 2015,

application in the detection of oral epithelial dysplasia and in situ and invasive squamous cell carcinomas. Oral Surg Oral Med Oral Pathol Oral Radiol Endod. 2001; 91:535-40. | Article | PubMed

40. Bruno MJ. Magnification endoscopy, high resolution endoscopy, and chromoscopy; towards a better optical diagnosis. Gut. 2003; 52 Suppl 4:iv7-11. | Article | PubMed Abstract | PubMed Full Text

41. Riaz A, Shreedhar B, Kamboj M and Natarajan S. Methylene blue as an early diagnostic marker for oral precancer and cancer. Springerplus. 2013; 2:95. | Article I PubMed

42. Salley JJ. Experimental carcinogenesis in the cheek pouch of the Syrian hamster. J Dent Res. 1954; 33:253-62. | Article | PubMed

43. Gimenez-Conti IB and Slaga TJ. The hamster cheek pouch carcinogenesis model. J Cell Biochem Suppl. 1993; 17F:83-90. | Article | PubMed

44. Santis $\mathrm{H}$ and Shklar G. A Histochemical Study of Human Oral Carcinoma. Oral Surg Oral Med Oral Pathol. 1964; 17:84-91. | Article | PubMed

45. Shklar G. Metabolic Characteristics of Experimental Hamster Pouch Carcinomas. Oral Surg Oral Med Oral Pathol. 1965; 20:336-9. | Article | PubMed

46. Solt DB. Localization of gamma-glutamyl transpeptidase in hamster buccal pouch epithelium treated with 7,12-dimethylbenz[a]anthracene. J Natl Cancer Inst. 1981; 67:193-200. | PubMed

47. Shin DM, Gimenez IB, Lee JS, Nishioka K, Wargovich MJ, Thacher S, Lotan R, Slaga TJ and Hong WK. Expression of epidermal growth factor receptor, polyamine levels, ornithine decarboxylase activity, micronuclei, and transglutaminase $I$ in a 7,12-dimethylbenz(a) anthracene-induced hamster buccal pouch carcinogenesis model. Cancer Res. 1990; 50:2505-10. | Article | PubMed

48. Odukoya $\mathrm{O}$ and Shklar G. Two-phase carcinogenesis in hamster buccal pouch. Oral Surg Oral Med Oral Pathol. 1982; 54:547-52. | Article | PubMed

49. Silberman S and Shklar G. The Effect of a Carcinogen (Dmba) Applied to the Hamster's Buccal Pouch in Combination with Croton Oil. Oral Surg Oral Med Oral Pathol. 1963; 16:1344-55. | Article | PubMed

50. Wong DT. Amplification of the c-erb B1 oncogene in chemically-induced oral carcinomas. Carcinogenesis. 1987; 8:1963-5. | Article | PubMed

51. Husain Z, Fei YB, Roy S, Solt DB, Polverini PJ and Biswas DK. Sequential expression and cooperative interaction of $\mathrm{c}$-Ha-ras and c-erbB genes in in vivo chemical carcinogenesis. Proc Natl Acad Sci U S A. 1989; 86:12648. | Article | PubMed Abstract | PubMed Full Text

52. Kwong YY, Husain $Z$ and Biswas DK. c-Ha-ras gene mutation and activation precede pathological changes in DMBA-induced in vivo carcinogenesis. Oncogene. 1992; 7:1481-9. | Article | PubMed

53. Schwartz J, Shklar G and Trickler D. p53 in the anticancer mechanism of vitamin E. Eur J Cancer B Oral Oncol. 1993; 29B:313-8. | Article | PubMed

54. Tsuji T, Duh FM, Latif F, Popescu NC, Zimonjic DB, McBride J, Matsuo K, Ohyama H, Todd R, Nagata E, Terakado N, Sasaki A, Matsumura T, Lerman $\mathrm{MI}$ and Wong DT. Cloning, mapping, expression, function, and mutation analyses of the human ortholog of the hamster putative tumor suppressor gene Doc-1. J Biol Chem. 1998; 273:6704-9. | Article I PubMed

55. Girod SC, Pfeiffer P, Ries J and Pape HD. Proliferative activity and loss of function of tumour suppressor genes as 'biomarkers' in diagnosis and prognosis of benign and preneoplastic oral lesions and oral squamous cell carcinoma. Br J Oral Maxillofac Surg. 1998; 36:252-60. | Article | PubMed

56. Wong DT, Todd R, Tsuji T and Donoff RB. Molecular biology of human oral cancer. Crit Rev Oral Biol Med. 1996; 7:319-28. | Article | PubMed

57. Shklar $\mathrm{G}$ and Schwartz J. A common pathway for the destruction of cancer-cells - experimental-evidence and clinical implications. Int $J$ Oncol. 1994; 4:215-24. | Article | PubMed

58. Tanaka T, Kojima T, Okumura A, Yoshimi N and Mori H. Alterations of the nucleolar organizer regions during 4-nitroquinoline 1-oxide-induced tongue carcinogenesis in rats. Carcinogenesis. 1991; 12:329-33. | Article I PubMed
59. Suzui M, Sugie S, Mori H, Okuno M, Tanaka T and Moriwaki H. Different mutation status of the beta-catenin gene in carcinogen-induced colon, brain, and oral tumors in rats. Mol Carcinog. 2001; 32:206-12. | Article I PubMed

60. Suzui M, Yoshimi N, Tanaka T and Mori H. Infrequent Ha-ras mutations and absence of $\mathrm{Ki}$-ras, $\mathrm{N}$-ras, and p53 mutations in 4-nitroquinoline 1-oxide-induced rat oral lesions. Mol Carcinog. 1995; 14:294-8. | Article I PubMed

61. Tsuda $H$, Asamoto M, Ochiya T, Toriyama-Baba H, Naito A, Ota T, Sekiya $T$ and Terada M. High susceptibility of transgenic rats carrying the human c-Ha-ras proto-oncogene to chemically-induced mammary carcinogenesis. Mutat Res. 2001; 477:173-82. | Article | PubMed

62. Asamoto M, Hokaiwado N, Cho YM, Ikeda Y, Takahashi S and Shirai T. Metastasizing neuroblastomas from taste buds in rats transgenic for the Simian virus 40 large $T$ antigen under control of the probasin gene promoter. Toxicol Pathol. 2001; 29:363-8. | Article | PubMed

63. Asamoto M, Hokaiwado N, Cho YM and Shirai T. Effects of genetic background on prostate and taste bud carcinogenesis due to SV40 T antigen expression under probasin gene promoter control. Carcinogenesis. 2002; 23:463-7. | Article | PubMed

64. Kochi T, Shimizu M, Shirakami Y, Yoshimi K, Kuramoto T, Tanaka T and Moriwaki $\mathrm{H}$. Utility of Apc-mutant rats with a colitis-associated colon carcinogenesis model for chemoprevention studies. Eur J Cancer Prev. 2015; 24:180-7. | Article | PubMed

65. Yoshimi K, Hashimoto T, Niwa Y, Hata K, Serikawa T, Tanaka T and Kuramoto $\mathrm{T}$. Use of a chemically induced-colon carcinogenesis-prone Apc-mutant rat in a chemotherapeutic bioassay. BMC Cancer. 2012; 12:448. | Article | PubMed Abstract | PubMed Full Text

66. Yoshimi K, Tanaka T, Serikawa T and Kuramoto T. Tumor suppressor APC protein is essential in mucosal repair from colonic inflammation through angiogenesis. Am J Pathol. 2013; 182:1263-74. | Article | PubMed

67. Yoshimi K, Tanaka T, Takizawa A, Kato M, Hirabayashi M, Mashimo T, Serikawa T and Kuramoto T. Enhanced colitis-associated colon carcinogenesis in a novel Apc mutant rat. Cancer Sci. 2009; 100:2022-7. | Article | PubMed

68. Tanaka T, Shimizu M, Kochi T, Shirakami Y, Mori T, Watanabe N, Naiki T, Moriwaki H, Yoshimi K, Serikawa T and Kuramoto T. Apc-Mutant Kyoto Apc Delta (KAD) Rats Are Susceptible to 4-NQO-Induced Tongue Carcinogenesis. Cancers (Basel). 2014; 6:1522-39. | Article | PubMed Abstract I PubMed Full Text

69. Kasuga M, Ueki K, Tajima N, Noda M, Ohashi K, Noto H, Goto A, Ogawa W, Sakai R, Tsugane S, Hamajima N, Nakagama H, Tajima K, Miyazono $\mathrm{K}$ and Imai K. Report of the Japan Diabetes Society/Japanese Cancer Association Joint Committee on Diabetes and Cancer. Cancer Sci. 2013; 104:965-76. | Article | PubMed

70. Tanaka T, Miyamoto S, Yasui Y, Kohno H and Sugie S. Obesity: a risk for hepatocelullar carcinoma. In Tanaka T (ed.), Cancer: Disease Progression and Chemoprevention Research Signpost, Kerala (India), 2007; 57-74.

71. Yamada T, Hara K and Kadowaki T. Chewing betel quid and the risk of metabolic disease, cardiovascular disease, and all-cause mortality: a meta-analysis. PLoS One. 2013; 8:e70679. | Article | PubMed Abstract | PubMed Full Text

72. Cowan JM, Beckett MA, Ahmed-Swan S and Weichselbaum RR. Cytogenetic evidence of the multistep origin of head and neck squamous cell carcinomas. J Natl Cancer Inst. 1992; 84:793-7. | Article | PubMed

73. Williams HK. Molecular pathogenesis of oral squamous carcinoma. Mol Pathol. 2000; 53:165-72. | Article | PubMed Abstract | PubMed Full Text

74. Dewanji A, Goddard MJ, Krewski D and Moolgavkar SH. Two stage model for carcinogenesis: number and size distributions of premalignant clones in longitudinal studies. Math Biosci. 1999; 155:1-12. | Article | PubMed

75. Fearon ER and Vogelstein B. A genetic model for colorectal tumorigenesis. Cell. 1990; 61:759-67. | Article | PubMed

76. Forastiere A, Koch W, Trotti A and Sidransky D. Head and neck cancer. $N$ 
Watanabe et al. Oncology Discovery 2015,

http://www.hoajonline.com/journals/pdf/2052-6199-3-1.pdf

Engl J Med. 2001; 345:1890-900. | Article | PubMed

77. Califano J, van der Riet P, Westra W, Nawroz H, Clayman G, Piantadosi S, Corio R, Lee D, Greenberg B, Koch W and Sidransky D. Genetic progression model for head and neck cancer: implications for field cancerization. Cancer Res. 1996; 56:2488-92. | Article | PubMed

78. Tanaka T. Chemoprevention of oral carcinogenesis. Eur J Cancer B Oral Oncol. 1995; 31B:3-15. | Article | PubMed

79. Saba NF, Haigentz M, Jr., Vermorken JB, Strojan P, Bossi P, Rinaldo A, Takes RP and Ferlito A. Prevention of head and neck squamous cell carcinoma: removing the "chemo" from "chemoprevention". Oral Oncol. 2015; 51:112-8. | Article | PubMed

80. Bodhade AS and Dive AM. Chemoprevention of premalignant and malignant lesions of oral cavity: Recent trends. Eur J Dent. 2013; 7:24650. | Article | PubMed

81. Foy JP, Bertolus C, William WN, Jr. and Saintigny P. Oral premalignancy: the roles of early detection and chemoprevention. Otolaryngol Clin North Am. 2013; 46:579-97. | Article | PubMed Abstract | PubMed Full Text

82. James MJ and Cleland LG. Cyclooxygenase-2 inhibitors: what went wrong? Curr Opin Clin Nutr Metab Care. 2006; 9:89-94. | Article

83. Omenn GS, Goodman GE, Thornquist MD, Balmes J, Cullen MR, Glass A, Keogh JP, Meyskens FL, Jr., Valanis B, Williams JH, Jr., Barnhart S, Cherniack MG, Brodkin CA and Hammar S. Risk factors for lung cancer and for intervention effects in CARET, the Beta-Carotene and Retinol Efficacy Trial. J Nat/ Cancer Inst. 1996; 88:1550-9. | Article | PubMed

84. Tanaka T. Chemoprevention of human cancer: biology and therapy. Crit Rev Oncol Hematol. 1997; 25:139-74. | Article | PubMed

\section{Citation:}

Watanabe N, Ohkubo T, Shimizu M and Tanaka T. Preneoplasia and carcinogenesis of the oral cavity. Oncol Discov. 2015; 3:1.

http://dx.doi.org/10.7243/2052-6199-3-1 